\title{
Chemical and Biological Evaluation of Whey
}

\author{
N. E. Mohamed and M. M. Anwar*
}

Biological Applications and *Plant Research Dept., Nuclear Research Centre (NRC), P.O. 13759 Box, Inshas, Egypt.

\begin{abstract}
$\mathrm{T}$ HIS STUDY has been carried out to extract whey protein concentrate (WPC) from sweet whey and to study the chemical composition, amino acids composition, amino acid scores and to investigate the possible role of WPC in ameliorating some biochemical disorders induced in $\gamma$-irradiated rats. Animals were divided into 4 groups. Group 1, fed on normal diet during experimental period. Group 2, fed on diet containing 15\% WPC instead of soybean protein. Group 3, rats exposed to whole body $\gamma$-radiation with single dose of $5 \mathrm{~Gy}$ and fed on the normal diet. Group 4, rats exposed to 5 Gy then fed on diet containing $15 \%$ WPC. The rats were decapitated 14 and 28 days post irradiation.

Chemical analysis of WPC revealed that it contains high amounts of protein (44\%), total amino acids (71\%) and all essential amino acids (EAA), phenylalanine (37\%), isoleucine cystine and threonine were the major EAA and high amounts of sulphur amino acids. Methionine gave rich chemical score $(102.67 \%)$ also, isoleucine $(119.95 \%)$ and phenylalanine+ tyrosine gave maximum chemical score $(198.8 \%)$, respectively. Exposure to $\gamma$-irradiation caused significant elevation of serum cholesterol, triglycerides, low density lipoprotein (LDL), lipid per oxidation end product (TBARS) and iron $(\mathrm{Fe})$ with significant decrease in high density lipoprotein (HDL), glutathione (GSH) and catalase (CAT) in serum. Also, irradiated rats had significant decrease in copper $(\mathrm{Cu})$, magnesium $(\mathrm{Mg})$ and zinc $(\mathrm{Zn})$ in serum. The histological examination of cardiac tissue showed severe structural damage. Irradiated rats fed on WPC revealed significant improvement of some biochemical parameters. It could be concluded that WPC must be added to diet for reducing radiation injury via metabolic pathway.

Keywords: Whey protein concentrate, oxidative stress, hyper lipidaemia, trace elements, irradiated rats.
\end{abstract}

Milk serum proteins are defined as substances that remain soluble in milk serum. These proteins are naturally formed during the production of cheese and account of $20 \%$ of all protein in milk (Pal et al., 2010), such as $\beta$ - lactoglobulins, 
$\alpha$-lactalbumin, immunoglobulin, lactoferrin, lactoperoxidase, glycomacropeptide, bovine serum albumin and other proteins (Hulmi et al., 2010). WPC derived from milk have antioxidant, antihypertensive, antitumor, hypolipidaemic, antiviral, antibacterial and chelating properties. WPC also, possesses bioactive substances such as tissue growth factors, hormones, insulin like growth factor (IGFs), transforming growth factor-B (TGF-B), which have an important physiological role (Sukkar and Bounous, 2004). WPC do not coagulate in acidic conditions and rapidly digested and raise plasma amino acid concentrations (Pal and Ellis, 2010). Therefore, milk serum proteins perform several functions, such as mineral absorption, improvement of protein synthesis, sensitivity to hormones and decreased blood glucose and lipid levels (Sousa et al., 2012). WP supplementation may be beneficial for improving the healing and closure of diabetic wounds (Badr, 2013). The improved protection of whey protein product by lycosome could allow people to improve their metabolic parameters, vascular function and antiageing microcirculation (Petyaev et al., 2012). Whey protein hydrolysate is the potential protector against paracetamol induced hepato-nephrotoxicity and can be effectively used in health promoting foods as a bio functional ingradient (Athira et al., 2013). Also, whey protein isolate dietary supplements may be effective in slowing the development of fatty liver disease and type-2 diabetes (Shertzer et al., 2011).

Radiotherapy has become a routine treatment for various types of malignancies; severe adverse side effects commonly rise from radiotherapy (Oh et al., 2004). The strategies of therapy become capable of protecting normal host tissue from lethal actions of radiation (Nair et al., 2001).

It is generally accepted that endogenous-antioxidants, such as cellular nonprotein thiols and antioxidant enzymes, provide some degree of protection (Miranda-Vilela et al., 2012). During radiotherapy, ionizing irradiation interact with biological system to induce reactive oxygen species (ROS), Thus, scavenging ROS and inhibiting lipid per oxidation are likely key target activities for developing successful radio protection strategies (Kunwar et al., 2010).

Therefore, the objective of the present study was to investigate the role of WPC as a radio therapeutic agent or radio recovery against $\gamma$-radiations on some biochemical aspects and the antioxidant status in female rats and the probable mechanisms by which WPC exerts its recovery role.

Egypt. J. Rad. Sci. Applic., Vol. 26, No. 1-2 (2013) 


\section{Material and Methods}

\section{Animals}

Forty eight adult female albino rats weighing $140 \pm 10 \mathrm{~g}$ were used. The animals were obtained from animal house of NRC, Inshas, Egypt and were supplied with balanced standard diet and water ad libitum. WPC diet was prepared according to Anwar and Mohamed (2009).

\section{Extraction of WPC}

WPC was prepared from dried sweet whey. Spray dried sweet whey powder imported from "METEL MANN" Company; Hamburg, Germany $(1.0 \%$ fat maximum and moisture 4.0\%) was used in this study for the preparation of WPC. Sweet whey powder was reconstituted in distilled water to a concentration of $20.0 \%$ and $\mathrm{pH}$ was adjusted to 4.6 with concentrated $\mathrm{HCl}$. Reconstituted whey was heated in a water bath at $90^{\circ} \mathrm{C} / 30 \mathrm{~min}$. and drained through cloth. The collected whey was separated on try and dried in an oven at $45^{\circ} \mathrm{C}$ (Mathews, 1984).

\section{Chemical composition of WPC}

Protein, fat and ash content of WPC were determined according to the official methods described by (A.O.A.C., 2005). Table 1. represent the composition of the experimental diet, which composed of $51.55 \%$ starch, $18.15 \%$ protein, $17.93 \%$ sucrose, $5.15 \%$ corn oil, $5.15 \%$ cellulose and $2.07 \%$ vitamins and minerals according to (NRC, 1977).

TABLE 1. Composition of the experimental rat feeding diets

\begin{tabular}{|c|c|c|}
\hline Items & Control diet \% & WPC diet \% \\
\hline Corn & 67.74 & 64.44 \\
\hline Soy protein & 27.40 & 15.70 \\
\hline Whey protein concentrate & 0.00 & 15.00 \\
\hline Vegetable oil & 1.60 & 1.60 \\
\hline Dicalcium phosphate & 1.70 & 1.70 \\
\hline Limostone & 0.90 & 0.90 \\
\hline Common salt & 0.30 & 0.30 \\
\hline $\begin{array}{c}\text { Vitamins and minerals } \\
\text { (premix) }\end{array}$ & 0.30 & 0.30 \\
\hline Methionine & 0.06 & 0.06 \\
\hline
\end{tabular}




\section{Amino acid analysis}

Amino acid composition of WPC was carried out in the Agriculture Research Centre, Central Laboratory for Food and Feed. Amino acid content was determined according to methods of A.O.A.C. (2005). Five milligram of the powder sample was weighed and placed in $2 \mathrm{ml}$ ampoules, to which the internal standard (norleucine) and $0.45 \mathrm{ml}$ of $6 \mathrm{~N} \mathrm{HCl}$ were added. Norleucine was used as internal standard because it is an amino acid not commonly found in proteins. The ampoules were evacuated, sealed and placed in an oven for $24 \mathrm{~h}$ at $110^{\circ} \mathrm{C}$. After hydrolysis, $20 \mu \mathrm{l}$ aliquots of the hydrolysates were dried, mixed with $10 \mu 1$ of redry solution (ethanol: water: triethylamine, 2: 2: $1 \mathrm{v} / \mathrm{v}$ ), dried again and finally derivatized with $20 \mu \mathrm{l}$ pheny liso thiocynide reagent (ethanol: water: triethylamine: phenylisothiocyanide, 7: 1: 1: $1 \mathrm{v} / \mathrm{v}$ ) for $20 \mathrm{~min}$ at room temperature. Excess reagent was removed with the aid of a vacuum at room temperature. Derivetized samples were dissolved in $0.1 \mathrm{ml}$ of $0.14 \mathrm{M}$ sodium acetate that had been adjusted to $\mathrm{pH} 6.4$ with dilute acetic acid. A $20 \mu 1$ aliquot was injected onto the column. Quantization of amino acid was performed using a Waters C18 column $(3.5 \times 150 \mathrm{~mm})$ with gradient conditions as described elsewhere. Derivatized amino acids were eluted from the column with increasing concentrations of acetonitrile. The elute was monitored at $254 \mathrm{~nm}$ and the areas under the peaks were used to calculate the concentrations of the unknowns using the Pierce standard $\mathrm{H}$ amino acid calibration mixture (Rock ford, IL). Norleucine was the internal standard used in all amino acid determinations. A sample of egg white lysozyme analyzed in duplicate, served as the control protein. Samples intended for the determination of cysteine were first oxidized with performic acid (80\% formic acid and 30\% hydrogen peroxide, 9: 1) for $18 \mathrm{~h}$ at room temperature. The oxidizing reagent was removed with the aid of an evaporative centrifuge and the samples were with $6 \mathrm{~N} \mathrm{HCl}$ as described above. The tryptophan content was determined in a separate analysis. The weighed samples were placed in polypropylene tubes and after the addition of the internal standard (norleucine); they were hydrolyzed in $4.67 \mathrm{M} \mathrm{KOH}$ containing $1 \% \mathrm{w} / \mathrm{v}$ thiodiglycol for $18 \mathrm{~h}$ at $110^{\circ} \mathrm{C}$. After hydrolysis the $\mathrm{KOH}$ was neutralized with $2.4 \mathrm{M}$ perchloric acid, and the supernatant was adjusted $\mathrm{pH} 3.0$ with acetic acid. A $20 \mu \mathrm{l}$ aliquot of the hydrolysed sample was subjected to derivatization as described above. The solution of amino acid standard was 
supplemented with tryptophan. Quality assurance of the tryptophan determination was obtained by demonstrating that method yielded the correct number of tryptophan residues for egg white lysozyme. Tryptophan analysis was performed using a Waters C18 reversed phase column (3.9x150mm) (Waters Milford, MA) and the solvents and gradient conditions. Use of this elution protocol was necessary in order to adequately separate tryptophan from ornithine which results from the alkaline hydrolysis of arginine. Amino acid score was calculated according to FAO/WHO, (1985) as follows: Amino acid score $=\mathrm{mg}$ of amino acid in one $\mathrm{g}$ test protein $/ \mathrm{mg}$ of amino acid in FAO reference pattern X100.

\section{Experimental design}

The animals were divided randomly into four groups (12 rats /each). Group1, rats served as a control and fed on normal diet. Group 2, rats fed on diet containing 15\% WPC instead of soybean protein. Group 3, rats were exposed to whole body $\gamma$-radiation with single dose level of 5Gy then fed on normal diet. Group 4, rats were exposed to whole body $\gamma$-radiation with single dose level of 5Gy and fed on WPC diet. Radiation source was cobalt-60 cell 3500 belonged to Middle Eastern Regional Radioisotope Centre for the Arab Countries (MERRCAC) in Dokki, Giza, Egypt. Six rats from each group were sacrificed after an overnight fasting at two time intervals after 14 and 28 days post irradiation. Blood samples were collected in plain tubes to separate sera. Sera samples were used for the analysis of cholesterol, triglycerides, HDL and LDL according to Allian et al. (1974), Fossati and Principe (1982), Demacker et al. (1980) and Friedewald et al. (1972), respectively. Serum level of TBARS, GSH and CAT were determined as described by Yoshioka et al. (1979), Beutler et al. (1963) and Takahara et al. (1960), respectively. Serum level of Fe, Zn, Cu and $\mathrm{Mg}$ was determined using Buck Scientific model 210 Atomic Absorption Spectrometer.

\section{Histological examination}

Samples of heart were taken from rats under investigation and fixed in $10 \%$ neutral formalin and embedded in paraffin blocks then cut into $6 \mu \mathrm{m}$ sections. They were stained with haematoxylin and eosin then examined with light microscope. 


\section{Statistical analysis}

The obtained data of treated rats at two interval times 14 and 28 days in all previous studies were compared using one way analysis of variance (ANOVA) followed by Duncan multiple range test (Duncan, 1955).

\section{Results}

The chemical composition of WPC is given in Table 2. it contains $44 \%$ protein, $5 \%$ fat, $4.6 \%$ ash and $46.4 \%$ lactose on dry wt. The amino acid content of WPC was listed in Table 3. it contains $71 \%$ total amino acids and had high amounts of sulphur amino acids. Cysteine, isoleucine, lysine, phenylalanine, threonine, tyrosine and valine were the major EAA, total EAA was 37\%. Table 4. illustrated that leucine, lysine and valine are most limiting in EAA also, sulphur amino acid (methionine) gave rich chemical score $102.76 \%$ and phenylalanine+ tyrosine and isoleucine gave maximum chemical score 198.8 and $119.95 \%$ respectively. Data in Table 5. show significant increase in cholesterol, triglycerides, LDL and TBARS in irradiated rats when compared to the other three groups.

Table (2): Chemical compositions of whey protein concentrate.

\begin{tabular}{|c|c|c|c|c|}
\hline \% by dry wt & Protein & Fat & Ash & Lactose \\
\hline Whey protein concentrate & 44 & 5 & 4.6 & 46.4 \\
\hline
\end{tabular}

Table (3): Amino acid composition of whey protein concentrates.

\begin{tabular}{|c|c|c|c|c|c|}
\hline \multicolumn{2}{|c|}{ Amino acids } & $\begin{array}{c}\text { FAO/WHO } \\
\text { AA pattern\% }\end{array}$ & \multicolumn{2}{c|}{ Amino acids } & $\begin{array}{c}\text { FAO/WHO AA } \\
\text { pattern \% }\end{array}$ \\
\hline EAA & $\mathrm{g} / 100$ & & Non-EAA & $\mathrm{g} / 100 \mathrm{~g}$ & \\
\hline Cysteine & 4.6796 & & Alanine & 3.0916 & \\
\hline Isoleucine & 5.5177 & 4.6 & Arginine & 5.4156 & \\
\hline Leucine & 1.4976 & 4.8 & Aspartic acid & 4.2283 & 2.24 \\
\hline Lysine & 3.9817 & 5.5 & Glutamic acid & 2.5702 & \\
\hline Methionine & 2.2589 & 2.2 & Glycine & 4.949 & \\
\hline Phenylalanine & 5.5673 & 2.8 & Histidine & 2.8963 & 2.6 \\
\hline Threonine & 4.6682 & 4.3 & Proline & 4.8739 & \\
\hline Tryptophane & 1.4792 & 1.0 & Serine & 6.0913 & \\
\hline Tyrosine & 4.053 & & & & \\
\hline Valine & 3.4171 & 5.0 & & & \\
\hline Total EAA & 37.1203 & & Total non-EAA & 34.1162 & \\
\hline $\begin{array}{c}\text { Total AA } \\
\text { determined }\end{array}$ & 71.2365 & & & & \\
\hline
\end{tabular}

$\mathrm{AA}=$ Amino acids.

$\mathrm{EAA}=$ Essential amino acid.

Egypt. J. Rad. Sci. Applic., Vol. 26, No. 1-2 (2013) 
There were significant decreases in HDL, GSH and CAT in irradiated rats as compared to control group. Feeding irradiated rats on WPC diet restored the levels of, lipid metabolites, TBARS, GSH and CAT (Table 5). Radiation induced alteration in trace elements. Iron was significantly increased while $\mathrm{Cu}$, $\mathrm{Mg}$ and $\mathrm{Zn}$ were significantly decreased (Table 6). Feeding on WPC diet after irradiation restored the levels of trace elements compared to irradiated rats.

TABLE 4. Amino acid scores of whey protein concentrate on the reference pattern of amino acid.

\begin{tabular}{|l|c|}
\hline Amino acid & Amino acid score \\
\hline Leucine & 31.20 \\
\hline Isoleucine & 119.95 \\
\hline Lysine & 72.39 \\
\hline Methionine & 102.67 \\
\hline Phenylalanine + Tyrosine & 198.80 \\
\hline Threonine & 108.56 \\
\hline Valine & 68.34 \\
\hline
\end{tabular}

TABLE 5. Changes induced by whey protein concentrate feeding to 5.0Gy irradiated rats on serum lipid profile; TBARS, GSH and Catalase.

\begin{tabular}{|c|c|c|c|c|c|}
\hline Parameter & $\begin{array}{c}\text { Intervals } \\
\text { / days }\end{array}$ & Control & WPC & Irradiated & $\begin{array}{l}\text { Irradiated } \\
+\mathrm{WPC}\end{array}$ \\
\hline \multirow{2}{*}{$\begin{array}{c}\text { Cholesterol } \\
\mathrm{mg} / \mathrm{dl}\end{array}$} & 14 & $70.94 \pm 4.62^{\mathrm{cb}}$ & $67.64 \pm 2.71^{\mathrm{c}}$ & $122.48 \pm 8.98^{\mathrm{a}}$ & $75.22 \pm 1.28^{\mathrm{b}}$ \\
\hline & 28 & $65.75 \pm 2.17^{\mathrm{cb}}$ & $63.82 \pm 4.65^{\mathrm{dcb}}$ & $115.20 \pm 1.10^{a}$ & $70.26 \pm 1.75^{b}$ \\
\hline \multirow{2}{*}{$\begin{array}{c}\text { Triglycerides } \\
\mathrm{mg} / \mathrm{dl}\end{array}$} & 14 & $92.49 \pm 3.26^{\mathrm{c}}$ & $76.68 \pm 2.71^{d}$ & $162.53 \pm 3.79^{\mathrm{a}}$ & $142.23 \pm 2.49^{b}$ \\
\hline & 28 & $94.32 \pm 4.41^{\mathrm{c}}$ & $90.89 \pm 3.16^{\mathrm{cd}}$ & $129.18 \pm 2.21^{\mathrm{a}}$ & $115.98 \pm 4.22^{\mathrm{b}}$ \\
\hline \multirow{2}{*}{$\begin{array}{l}\text { HDL } \\
\mathrm{mg} / \mathrm{dl}\end{array}$} & 14 & $73.67 \pm 1.64^{\mathrm{a}}$ & $74.91 \pm 1.89^{\mathrm{a}}$ & $56.57 \pm 2.12^{b}$ & $72.67 \pm 5.01^{\mathrm{a}}$ \\
\hline & 28 & $72.90 \pm 2.02^{\mathrm{a}}$ & $71.24 \pm 2.21^{\mathrm{a}}$ & $60.86 \pm 1.14^{b}$ & $74.10 \pm 2.12^{\mathrm{a}}$ \\
\hline \multirow{2}{*}{$\begin{array}{l}\mathbf{L D L} \\
\mathrm{mg} / \mathrm{dl}\end{array}$} & 14 & $21.23 \pm 3.09^{b}$ & $22.61 \pm 2.93^{b}$ & $33.40 \pm 1.99^{\mathrm{a}}$ & $25.90 \pm 2.67^{b}$ \\
\hline & 28 & $26.01 \pm 0.54^{b}$ & $25.60 \pm 0.88^{\mathrm{cb}}$ & $30.77 \pm 1.70^{\mathrm{a}}$ & $27.04 \pm 1,11^{\text {abc }}$ \\
\hline \multirow{2}{*}{$\begin{array}{l}\text { TBARS } \\
\mathrm{nmol} / \mathrm{dl}\end{array}$} & 14 & $2.61 \pm 0.21^{\mathrm{c}}$ & $1.53 \pm 0.19^{\mathrm{d}}$ & $4.39 \pm 0.14^{\mathrm{a}}$ & $3.27 \pm 0.29^{\mathrm{bc}}$ \\
\hline & 28 & $2.32 \pm 0.16^{b}$ & $2.16 \pm 0.10^{\mathrm{b}}$ & $3.79 \pm 0.16^{\mathrm{a}}$ & $2.52 \pm 0.21^{\mathrm{b}}$ \\
\hline \multirow{2}{*}{$\begin{array}{l}\text { GSH } \\
\mathrm{mg} / \mathrm{dl}\end{array}$} & 14 & $3.96 \pm 0.27^{\mathrm{a}}$ & $3.11 \pm 0.42^{\mathrm{a}}$ & $1.86 \pm 0.29^{\mathrm{b}}$ & $3.39 \pm 0.39^{\mathrm{a}}$ \\
\hline & 28 & $4.52 \pm 0.46^{\mathrm{a}}$ & $3.96 \pm 0.23^{\mathrm{a}}$ & $2.19 \pm 0.19^{b}$ & $4.24 \pm 0.28^{\mathrm{a}}$ \\
\hline \multirow{2}{*}{$\begin{array}{c}\text { Catalase } \\
\mathrm{U} / \mathrm{L}\end{array}$} & 14 & $46.68 \pm 0.91^{a}$ & $48.31 \pm 1.08^{\mathrm{a}}$ & $15.43 \pm 1.47^{c}$ & $39.18 \pm 1.46^{b}$ \\
\hline & 28 & $59.42 \pm 2.04^{\mathrm{a}}$ & $56.20 \pm 1.04^{\mathrm{a}}$ & $25.46 \pm 2.89^{\mathrm{c}}$ & $47.84 \pm 0.89^{b}$ \\
\hline
\end{tabular}

Each value represents the mean \pm S.E. of 6 rats/ group.

The different small letters in the same row are significantly different at $P<0.05$. 
TABLE 6. Effect of whey protein concentrate feeding on serum $\mathrm{Fe}, \mathrm{Cu}, \mathrm{Mg}$ and $\mathrm{Zn}$ in different animal groups.

\begin{tabular}{|c|c|c|c|c|c|}
\hline Parameter & $\begin{array}{c}\text { Intervals/ } \\
\text { days }\end{array}$ & Control & WPC & Irradiated & $\begin{array}{c}\text { Irradiated } \\
+ \text { WPC }\end{array}$ \\
\hline $\begin{array}{c}\mathbf{F e} \\
\mu \mathrm{g} / \mathrm{dl}\end{array}$ & 14 & $166.11 \pm 2.03^{\mathrm{c}}$ & $168.13 \pm 2.13^{\mathrm{c}}$ & $185.85 \pm 3.11^{\mathrm{a}}$ & $175.95 \pm 1.06^{\mathrm{b}}$ \\
\cline { 2 - 6 } & 28 & $169.16 \pm 1.05^{\mathrm{b}}$ & $169.22 \pm 2.06^{\mathrm{b}}$ & $176.00 \pm 2.15^{\mathrm{a}}$ & $170.05 \pm 1.04^{\mathrm{b}}$ \\
\hline $\begin{array}{c}\mathbf{C u} \\
\mu \mathrm{g} / \mathrm{dl}\end{array}$ & 14 & $123.33 \pm 1.78^{\mathrm{a}}$ & $125.92 \pm 1.13^{\mathrm{a}}$ & $100.71 \pm 1.44^{\mathrm{c}}$ & $105.90 \pm 1.35^{\mathrm{b}}$ \\
\cline { 2 - 6 } & 28 & $129.82 \pm 1.81^{\mathrm{a}}$ & $130.06 \pm 1.46^{\mathrm{a}}$ & $112.84 \pm 1.13^{\mathrm{c}}$ & $120.18 \pm 1.76^{\mathrm{b}}$ \\
\hline $\begin{array}{c}\mathbf{M g} \\
\mu \mathrm{g} / \mathrm{dl}\end{array}$ & 14 & $4.81 \pm 0.06^{\mathrm{a}}$ & $4.91 \pm 0.15^{\mathrm{a}}$ & $2.16 \pm 0.08^{\mathrm{c}}$ & $3.05 \pm 0.04^{\mathrm{b}}$ \\
\cline { 2 - 6 } & 28 & $4.94 \pm 0.04^{\mathrm{a}}$ & $4.96 \pm 0.08^{\mathrm{a}}$ & $3.16 \pm 0.04^{\mathrm{c}}$ & $3.87 \pm 0.06^{\mathrm{b}}$ \\
\hline $\begin{array}{c}\mathbf{Z n} \\
\mu \mathrm{g} / \mathrm{dl}\end{array}$ & 14 & $89.23 \pm 1.23^{\mathrm{a}}$ & $91.13 \pm 1.04^{\mathrm{a}}$ & $64.8 \pm 2.68^{\mathrm{c}}$ & $79.77 \pm 3.40^{\mathrm{b}}$ \\
\cline { 2 - 6 } & 28 & $91.09 \pm 1.91^{\mathrm{ab}}$ & $93.10 \pm 2.05^{\mathrm{a}}$ & $70.90 \pm 1.11^{\mathrm{c}}$ & $85.11 \pm 1.94^{\mathrm{b}}$ \\
\hline
\end{tabular}

Each value represents the mean \pm S.E. of 6 rats/ group.

The different small letters in the same row are significantly different at $P<0.05$.

\section{Histological examination}

Microscopically, heart of rat from control group revealed the normal histological structure of cardiac tissue (Fig. 1). Similarly, heart of rat from WPC group for 14 days of feeding revealed no changes (Fig. 2) also, after 28 days of WPC feeding, the cardiac tissue showed no histopathological changes (Fig. 5). On the other hand, heart of rat from irradiated group showed congestion of myocardial blood vessel and myolysis of focal myocytes associated with few leucocytic cells infiltration (Fig, 3).
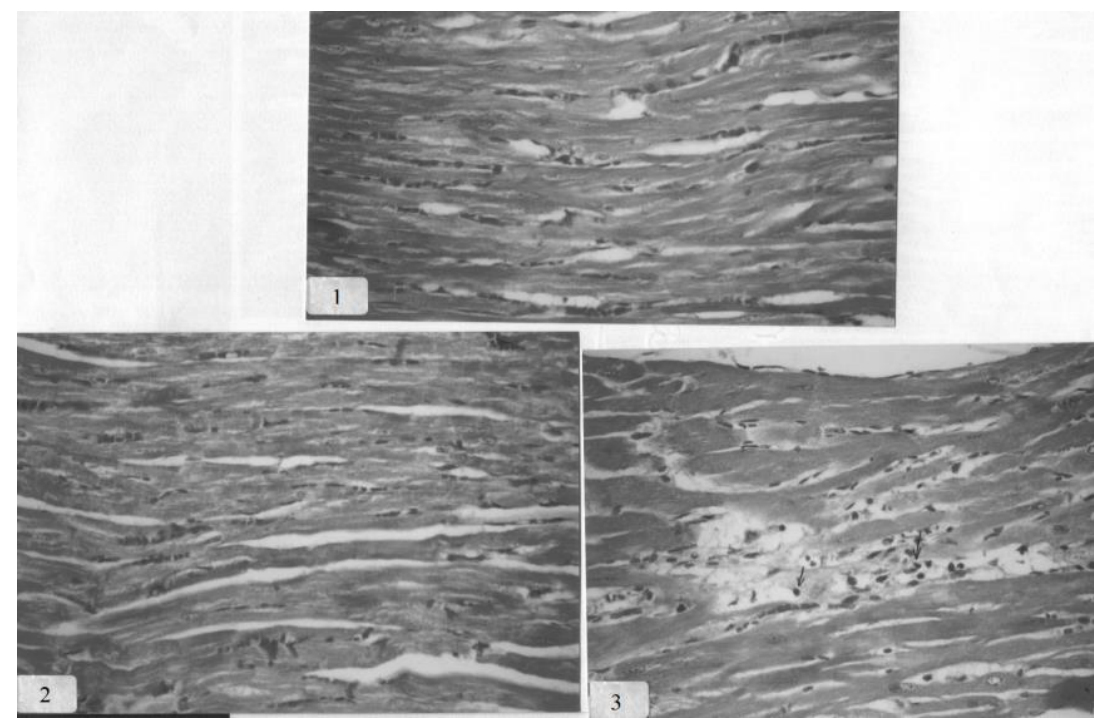

Fig. 1, 2, 3. Control, WPC (14 days) and Irradiated (14 days) groups. (H \&E X200).

Egypt. J. Rad. Sci. Applic., Vol. 26, No. 1-2 (2013) 
After 28 days of irradiation, heart of rat showed perivascular oedema associated with inflammatory cells infiltration and dilation and congestion of myocardial blood vessels (Fig. 6) Some examined sections from Group 4. of irradiated rats and feed on WPC diet for 14 days showed congestion of myocardial blood vessel while other sections from the same group showed no histopathological changes (Fig. 4) Also, after 28 days of irradiation no histopathological finding except few congested blood capillaries was observed in some sections in cardiac tissue of irradiated rat feed on WPC (Fig. 7).

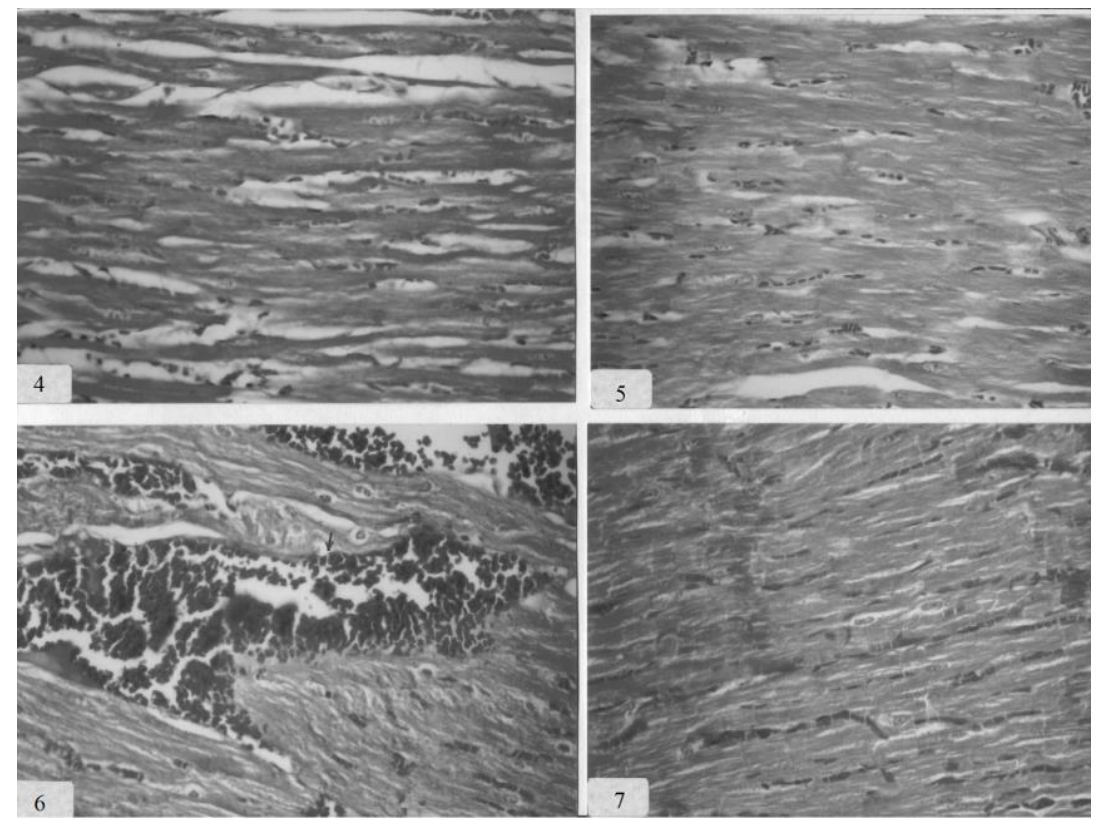

Fig. 4, 5, 6, 7. Irradiated and feed on WPC (14 days), WPC (28 days), Irradiated group (28 days) and Irradiated and feed on WPC (28 days) groups. (H \&E X200).

\section{Discussion}

Our results of chemical composition of WPC agree with Marshall (2004) he showed that it contains $25-89 \%$ protein and some fat, lactose and minerals which decrease as protein concentrate increases. The present results of amino acid content agree with Sousa et al. (2012). The present data revealed significant elevation in lipid profile and acceleration in lipid peroxidation end 
product due to exposure to ionizing radiation resulting in accumulation of cholesterol, triglycerides and other lipid metabolites. Our results are in agreement with those of Markevich and Kolomitseva (1994), who reported an increase of plasma lipid metabolites in irradiated rats. They attributed the hyperlipidaemic condition to the stimulation of cholesterol synthesis in the liver after $\gamma$-irradiation. The increase in serum triglycerides might result from inhibition of lipoprotein lipase activity, leading to reduction in the uptake of triacyl glycerols (Sedlakova et al., 1986). Feeding on WPC diet significantly improved these hyperlipidemia conditions due to changes in cholesterol solubility in the intestine (Pal et al., 2010). WPC contain certain bioactive components which may be responsible for the cholesterol reduction (Kawase et al., 2000).

Farnsworth et al. (2003) reported that increasing the ratio of protein in the diet is now considered a safe, effective strategy to enhance health by lowering blood lipid concentrations. These results became in accordance with Mohamed et al. (2010), who reported that irradiated male rats fed on WPC diet improve liver functions. Irradiation at the dose level of 5 Gy resulted in increased oxidative stress manifested by the significant increase in TBARS level as an indication for lipid peroxidation. These results are in agreement with (Vicentini et al., 2011). Feeding rats a diet contain WPC significantly ameliorate TBARS levels however whey products provide active (lactoferrin/ metal binding activities). Lactoferrin has the ability to strongly inhibit $\mathrm{Fe}$-dependant free radical reactions by directly binding to $\mathrm{Fe}$ (Reiter, 1985).

The results showed that feeding on WPC significantly elevated GSH level; WPC possesses potential anti oxidative activity in mitigation oxidative stress resulting from irradiation in rats. Our result became in agreement with Shoveller et al. (2005) who reported that GSH modulating effect of WPC is believed to enhancing the antioxidant actions of WPC. GSH protect cells against irradiation induced toxicity by detoxifying electrophiles, preventing oxidation of $\mathrm{SH}$ groups of proteins and by scavenging free radicals. WPC contain a concentration of cysteine that is at least 4 - fold higher than other high quality proteins (Bucci and Unlu, 2000). WPC is an effective cysteine donor that maintains a concentration of active GSH in Cells (Mariotti et al., 2004). CAT activity was significantly decreased in irradiated rats comparing with control group is probably related to its ability of the cell to cope with overproduction of

Egypt. J. Rad. Sci. Applic., Vol. 26, No. 1-2 (2013) 
$\mathrm{H}_{2} \mathrm{O}_{2}$ or $\mathrm{OH}$ these results agree with (Weiss and Landauer, 2003). The present results depicted that $\gamma$-radiation induced significant decreases in $\mathrm{Cu}, \mathrm{Mg}$ and $\mathrm{Zn}$ levels and significant increase in Fe levels throughout the experimental period. The metalloelement depression attributed to the radiolytic loss of essential metalloelement cofactors which account for the loss of both $\mathrm{Cu}$ and Mn SODs following irradiation. The increase in the level of Fe may be attributed to the inability of bone marrow to utilize the Fe available in the diet and released from destroyed cells or may correspond to the time of recovery of erythrocyte functions in the irradiated rat, also accumulation of $\mathrm{Fe}$ may result from disturbances in biological function of red blood cells (Kotb et al., 1990). On the other hand, the group fed on WPC indicated significant improvement of the Fe, $\mathrm{Cu} \mathrm{Mg}$ and $\mathrm{Zn}$ levels. WPC diet provides active lactoferrin is a metal binding activities (which is a Fe-chelating monomeric glycoprotein). Lactoferrin is a non haem iron binding glycoprotein and it comprising a single polypeptide chain with two binding sites for ferric ions, so whey lactoferrin exert its effects by regulating Fe absorption (Caccavo el al., 2002). Lactoferrin and lactoperoxidase fractions prevent $\mathrm{Fe}$ dependent free radical reactions (Reiter, 1985). WPC is a high quality source of $\mathrm{Ca}, \mathrm{Mg}$ and phosphorus (Walzem et al., 2002).

Irradiated rats showed damage to cardiac tissue may be due to the generation of the ROS metabolites which plays an important role in the pathogenesis of irradiation induced tissue injury these results agree with (Agrawal et al., 2001). Rats feed on WPC diet after irradiation showed normal cardiac tissue as compared to irradiated rats these result supported by Kent et al. (2003) who suggested that WPC fractions are linked to a range of bioactive functions such as prebiotic effects, promotion of tissue repair and elimination of toxins. Therefore it could be concluded that WPC could serve as a potential radio-recovering agent in rats through inhibition of ROS generation or their intensified scavenging, membrane repair, and enhancing other cells recovery.

\section{Acknowledgement}

The authors express their thanks to Dr. K. A. Ahmed, Assistant Prof. of Pathology, Faculty of Veterinary Medicine, Cairo University, Egypt, for her help in the histological examinations. 


\section{References}

A.O.A.C. (2005) "Official Methods of Analysis of the Association of Official Analytical Chemist". $15^{\text {th }}$ ed. Published by Association of Official Analytical Chemists, Arliugton, Virginia, USA.

Agrawal, A., Chandra, D. and Kale, R. K. (2001) Radiation induced oxidative stress. II Studies in liver as a distant organ of tumor bearing mice. Mol. Cellul. Biochem., 224, 9.

Allian, C. C., Poon, L. S., Chan, C. S., Richmond, W. and Fu, P. C. (1974) Enzymatic determination of total serum cholesterol. Clin. Chem., 20, 470.

Anwar, A. A. and N. E. Mohamed (2009) Influence of Whey protein for abrogating liver injury in female rats. Isotope \& Rad. Res., 41, 411.

Athira, S., Mann, B., Sharma, R. and Kumar, R. (2013) Ameilorative potential of whey protein hydrolysate against paracetamol-induced oxidative stress. $J$. Diary Sci., 96, 1341.

Badr, G. (2013) Camel whey protein enhances diabetic wound healing in a streptozotocin induced diabetic mouse model: the critical role of $\beta$-Defensin1,-2 and -3. Lipids Health Dis., 12, 46.

Beutler, E., Duran, O. and Kelly, B. M. (1963) Improved method for determination of blood glutathione. J. Lab. Clin. Med., 61, 882.

Bucci, L. R. and Unlu, L. (2000) Proteins and amino acids in exercise and sport. In Energy Yielding Macronutrients and Energy Metabolism in Sports Nutrition. Driskell, J. and Wolinsky, I. edits. CRC press. Boca Raton Fl., p. 197-200.

Caccavo, D., Pellegrino, N. M., Altamura, M., Rigon, A., Amati, L., Amoroso, A., Jirillo, E. (2002) Antimicrobial and immunoregulatory functions of lactoferrin and its potential therapeutic application. J. Endotoxin Res., 8, 403.

Demacker, P. N., Vos-Janssen, H. E., Hijman, A. G., Vant's Laar, A. and Jansen, A. P. (1980) Measurement of high density lipoprotein cholesterol in serum: comparison of six isolation methods combined with enzymatic cholesterol analysis. Clin. Chem., 26, 1780.

Duncan, D. B. (1955) Multiple range test and multiple F-tests. Biomet., 11, 41.

FAO/WHO (1973) Energy and Protein Requirements, WHO Technical Report Series No.522. FAO/ WHO, Geneva, Switzerland.

FAO/WHO (1985) Guidelines for development of supplementary foods for older infant and children. Joint FAO/WHO food standard programs. codex alimentaries commission report of the $14^{\text {th }}$ session of the codex committee on foods for special dietary uses, Bonn.

Farnsworth, E., Luscombe, N. D., Noakes, M., Wittert, G., Argyiou, E. and Clifton, P. M. (2003) Effect of a high protein, energy restricted diet on body composition, glycemic control and lipid concentrations in overweight and obes hyperinsulinemic men and women. Am. J. Cin. Nutr., 78, 31.

Egypt. J. Rad. Sci. Applic., Vol. 26, No. 1-2 (2013) 
Fossati, P. and Principe, L. (1982) Serum triglycerides determined colormetrically with an enzyme that produces hydrogen peroxide. Clin. Chem., 28, 2077.

Friedewald, W.T., Levy, R. I. and Fredrickson, D. S. (1972) Estimation of concentration of low density lipoprotein cholesterol in plasma without use of the preparative ultracentrifuge. Clin. Chem., 18, 499.

Hulmi, J. J., Lockwood, C. M. and Stout, J. R. (2010) Effect of protein/ essential amino acids and resistance training on skeletal muscle hypertrophy: A case for whey protein. Nutr. Metab., 7, 51.

Kawase, M., Hashimoto, H., Hosoda, M., Morita, H. and Hosono, A. (2000) effect of administration of fermented milk containing whey protein concentrate to rats and healthy men on serum lipids and blood pressure. J. Dairy Sci., 83, 255.

Kent, K. D., Harper, W. J. and Bomser, J. A. (2003) Effect of whey protein isolate on intracellular glutathione and oxidant-induced cell death in human prostate epithelial cells. Toxicol. In Vitro, 17, 27.

Kotb, M. A., Ramadan, M. I., El-Bassioni, E. A., El-Khatib, A. M. and Morsey, A. A. (1990) Changes in mineral elements in some tissues of mice following neutron irradiation. Isopenpaxis, 26, 297.

Kunwar, A., Bansal, P., Kumar, S., Bag, P., Paul, P., Reddy, N., Kumbhare, L., Jain, V., Chaubey, R., Unnikrishnan, M. and Priyadarsini, K. (2010) In vivo radioprotection studies of 3,3-diselenodipropionic acid a selenocystine derivative. Free Radic. Biol. Med., 48, 399.

Mariotti, F., Simbelie, K. L., Makarios-Lahham, L., Huneau, J. F., Laplaize, B., Tome, D. and Even, P. C. (2004) Acute ingestion of dietary proteins improves post-exercise liver glutathione in rats in a dose-dependent relationship with their cysteine content, J. Nutr., 134, 128.

Markevich, L. N. and Kolomitseva, I. K. (1994) Lipid from liver microsomes and mitochondria upon acute and chronic gamma-irradiation of rats. Biokhimiia, 59, 1027.

Marshall, K. (2004) Therapeutic applications of whey protein. Altern. Med. Rev., 9, 136.

Mathews, M. E. (1984) Whey protein recovery processes and products. J. Dairy Sci., 67, 2680.

Miranda-Vilela, A., Portilho, F., deAraujo, V., Estevanato, L., Mezzomo, B., Santos Mde, F. and Lacava, Z. (2012) The protective effects of nutritional antioxidant therapy on Ehrlich solid tumor-bearing mice depend on the type of antioxidant therapy chosen: histology, genotoxicity and hematology evaluations. J. Nut. Biochem., 22, 1091.

Mohamed, N. E., Anwar, M. M. and El-bostany, N. A. (2010) Biochemical studies on gamma irradiated male rats fed on whey protein concentrate, ARABJ. Nuc. Sci. Appl., 43, 263.

Egypt. J. Rad. Sci. Applic., Vol. 26, No. 1-2 (2013) 
Nair, C. K., Parida, D. K. and Nomura, T. (2001) Radiation protectors in radiotherapy. J. Rad. Res., 42, 21.

NRC (1977) National Research Council, Nutrient Requirement of Domestic Animals, Nutrient Requirements of Rat. National Academy of Science, Washington, DC, USA.

Oh, Y. T., Kim, C. H., Choi, J. H., Kang, S. H. and Chun, M. (2004) Sensory neural hearing loss after concurrent cisplatin and radiation therapy for nasopharyngeal carcinoma. Radiother. Oncol., 72, 79.

Pal, S. and Ellis, V. (2010) The acute effects of four protein meals on insulin, glucose, appetite and energy intake in lean men. Br. J. Nutr., 104, 1241.

Pal, S., Ellis, V. and Ho, S. (2010) Acute effects of whey protein isolate on cardiovascular risk factors in overweight, post-menopausal women. Atherosclerosis, 212, 339.

Petyaev, I. M., Dovgalevsky, P. Y., Klochkov, V. A., Chalyk, N. E. and Kyle, N. (2012) Whey protein lycosome formulation improves vascular functions and plasma lipids with reduction of markers of inflammation and oxidative stress in prehypertension. ScientificWorld Journal, 1100, 269476.

Reiter, B. (1985) The biological significance and exploitation of the non immunoglobulin protective proteins in milk: Lysozyme, lactoferrin, lactoperoxidase and xanthineoxidase. Bull Intern. Dairy Fed., 191, 2.

Sedlakova, A., Borikova,K. and Ahlers, L. (1986) Changes in lipoprotein lipase activity in the adipose tissue and heart of non lethal $\mathrm{X}$-irradiated rats. Physiol. Bohemoslev., 35, 400.

Shertzer, H. G.,Woods, S. E., Krishan, M., Genter, M. B. and Pearson, K. J. (2011) Dietary whey protein lowers the risk for metabolic disease in mice fed a high fat diet. J. Nutr., 141, 582.

Shoveller, A. K., Stoll, B., Ball, R. O. and Burrin, D. G. (2005) Nutritional and Functional importance of intestinal sulphur amino acid metabolism. J. Nutr., 135, 1609.

Sousa, G. T., lira, F.S., Rosa, J. C., de Oliveira, E. P., Oyama, L. M., Santos, R. V. and Pimentel, G. D. (2012) Dietary whey protein lessens several risk factors for metabolic diseases: a review. Lipidshealt Dis., 11, 67.

Sukkar, S. G. and Bounous, G. (2004) The role of whey protein in antioxidant defense. RINPE, 22, 193.

Takahara, S., Hamilton, H. B., Neel, J. V., Kobara, T. Y., Ogura, Y. and Nishimura, E. T. (1960) Hypocatalasemia: a new genetic carrier state. $J$. Clin. Invest., 39, 610.

Vicentini, F., He.T., Shao, Y., Fonseca, M. J., Verri WA. Jr., W., Fisher, G. and Xu. Y. (2011) Quercetin inhibits UV irradiation-induced inflammatory cytokine production in primary human keratinocytes by suppressing NF-KB pathway. J. Dermatol. Sci., 61, 162.

Egypt. J. Rad. Sci. Applic., Vol. 26, No. 1-2 (2013) 
Walzem, R. M., Dillard, C. L. and German, J. B. (2002) Whey components: millennia of evolution create functionalities for mammalian nutrition: what we know and what we may be overlooking, Crit. Rev. Food Sci. Nutr., 42, 353.

Weiss, J. F. and Landauer, M. R. (2003) Protection against ionizing radiation by antioxidant nutrients and phytochemicals. Toxicology, 189, 1.

Yoshioka, T., Kawada, K., Shimada, T. and Mori, M. (1979) Lipid peroxidation in maternal and cord blood and protective mechanism against activated-oxygen toxicity in the blood. Am. J. Obstet. Gynecol., 135, 372.

(Received: 13/08/2013;

accepted: $31 / 10 / 2013)$ 


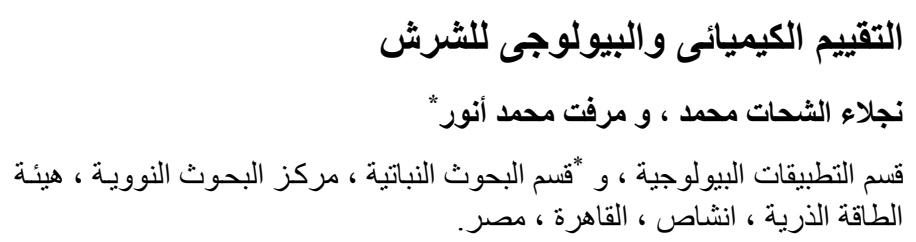

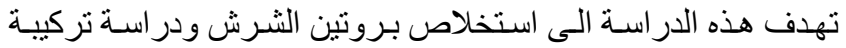

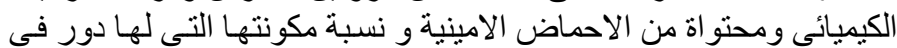

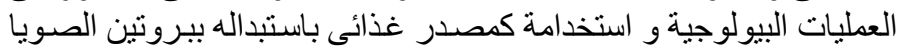

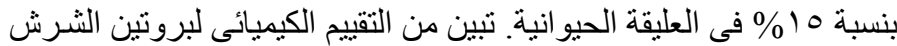

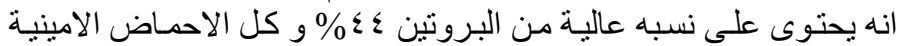

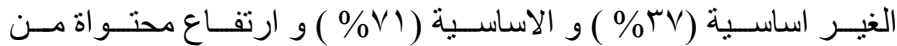

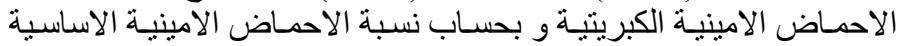

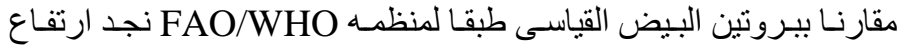

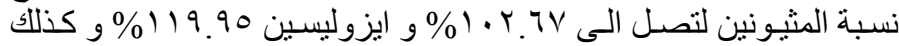

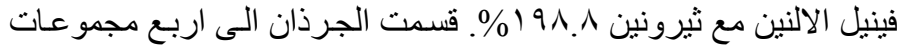

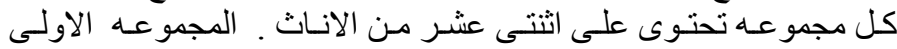

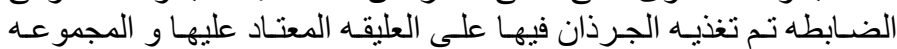

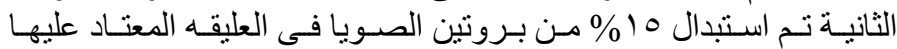

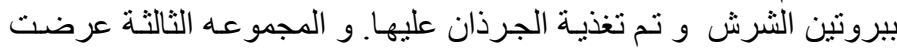

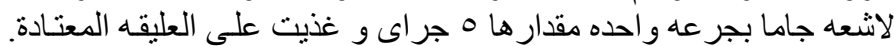

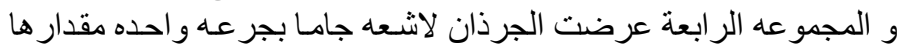

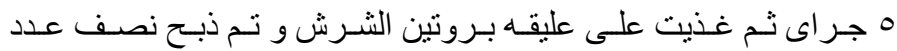

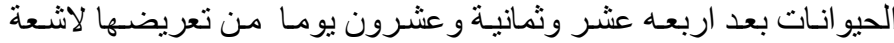

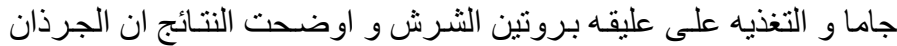

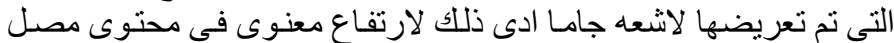

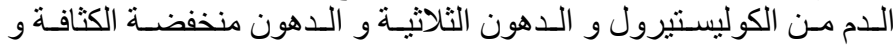

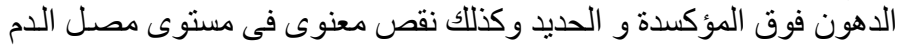

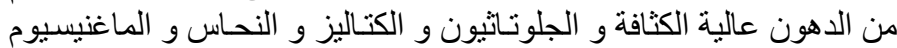

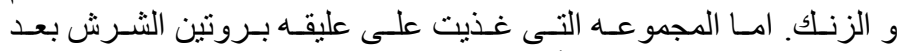

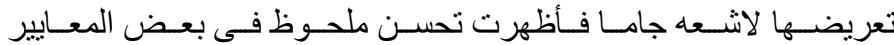

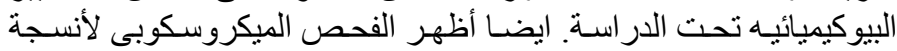

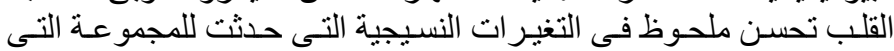

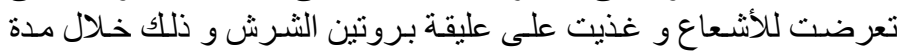

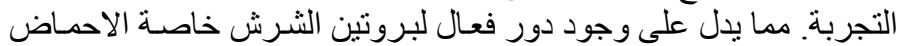

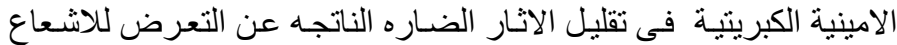

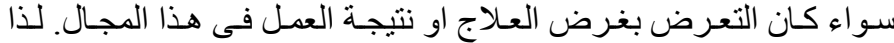
ينصح بأضافه بروتين الثرش الى الوجنة الغذائية.

Egypt. J. Rad. Sci. Applic., Vol. 26, No. 1-2 (2013) 